\title{
COVID-19 pandemic: Challenges and approaches in blood transfusions
}

\author{
Setare Kheyrandish ${ }^{1}{ }^{1}$, Amirhossein Rastgar ${ }^{1}{ }^{1}$, Farshid Abedi ${ }^{\left({ }^{2}\right.}{ }^{2}$, \\ Ebrahim Miri-Moghaddam
}

\begin{abstract}
One of the goals of the Iranian Blood Transfusion Organization is to provide adequate healthy blood and reduce the risk of various viral and bacterial transmission infections. With the removal of alternative blood donation, all blood units and blood products are provided through voluntary blood donation in Iran. The Blood Transfusion Organization screens the donated blood according to standard guidelines to ensure blood recipients and physicians of providing healthy and pathogen-free components. With the emergence of novel pathogens, such as the pandemic of the COVID-19 virus, despite Iran's self-sufficiency in blood supply and blood products, the number of blood donors has decreased significantly since there is a lack of comprehensive information on pathophysiology and virus transmission ways. Moreover, the existence of some shortages in screening programs can cause problems. Therefore, this study was performed to review the studies conducted investigating this emerging virus regarding blood transfusions and the supply of blood components worldwide.
\end{abstract}

Keywords: Blood banking, Blood components, Blood transfusion, COVID-19, Donor

Citation: Kheyrandish S, Rastgar AH, Abedi F, Miri-Moghaddam E. [COVID-19 pandemic: Challenges and approaches in blood transfusions]. J Birjand Univ Med Sci. 2021; 28(1): 1-10. [Persian]

DOI http://doi.org/10.32592/JBirjandUnivMedSci.2021.28.1.100

Received: April 14, $2020 \quad$ Accepted: August 5, 2020

\footnotetext{
${ }^{1}$ Student Research Committee, Department of Hematology and Blood Bank, School of Paramedical Sciences, Birjand University of Medical Sciences, Birjand, Iran

${ }^{2}$ Infectious Diseases Research Center, Department of Infectious, Faculty of Medicine, Birjand University of Medical Sciences, Birjand, Iran

${ }^{3}$ Cardiovascular Diseases Research Center, Department of Molecular Medicine, Faculty of Medicine, Birjand University of Medical Sciences, Birjand, Iran
}

Corresponding author: Cardiovascular Diseases Research Center, Department of Molecular Medicine, Faculty of Medicine, Birjand University of Medical Sciences, Birjand, Iran.

Tel: +985631626461

E-mail: moghaddam4@yahoo.com 


\title{
جالش و راهكارهاى يش رو در انتقال خون در ياندمى كوويد 19
}

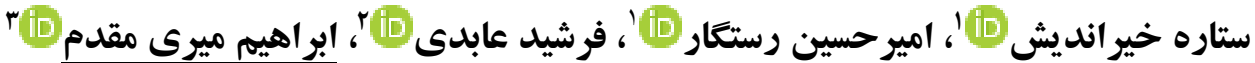

\begin{abstract}
جـيله

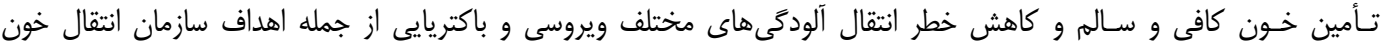

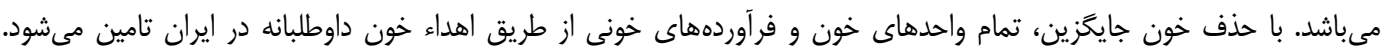

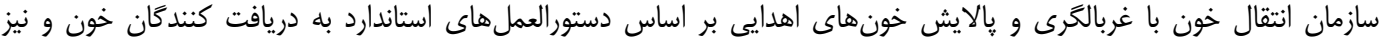

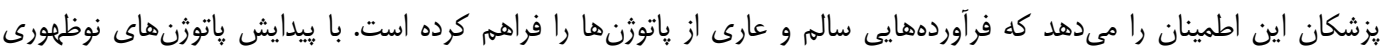

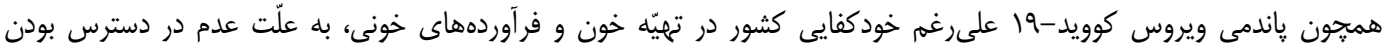

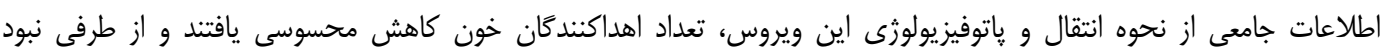

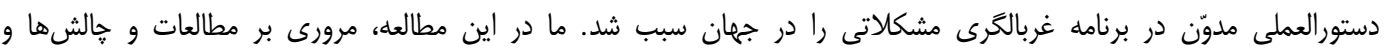

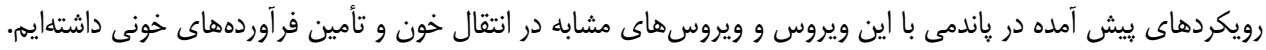
وازههاى كليدى: انتقال خون، فر آوردهاى خونى، تزريق خون، ويروس كوويد-19، اهداكنده

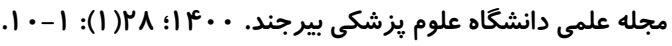
دريافت:
\end{abstract}

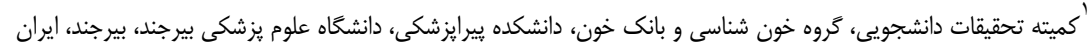

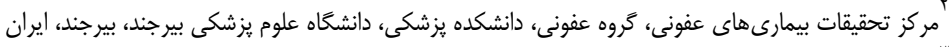

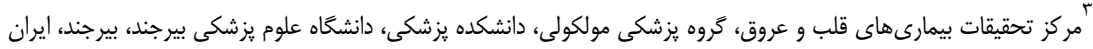

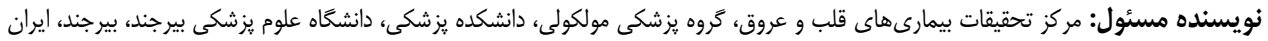

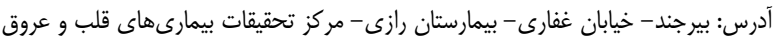

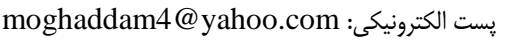

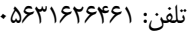


مطالعات اخير غلظت بسيار كمى از اين ويروس را در نمونههاى

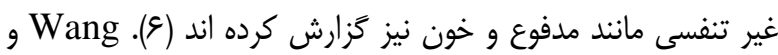

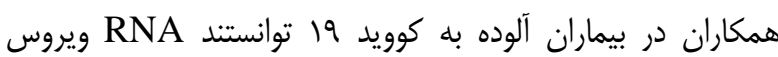
, SARS-CoV-2 خون و در هيج يك از نمونههاى ادرار كزارش كردند (V). سوابق ندان

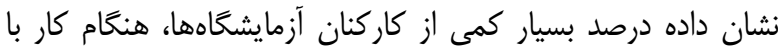
نمونهاى حاوى MERS-CoV و بيمارى هاى ويروسى مبتلا شدهاند. با اين حال كار با نمونههاى آلوده

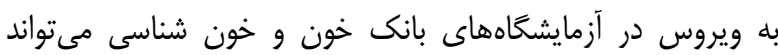

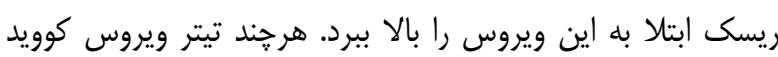

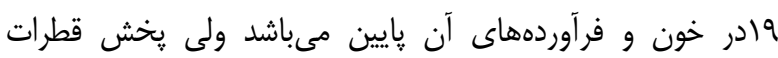
معلّق، ناشى از كار با نمونههاى آلوده به اين ويروس ممكن است است درد نهايت منجر به انتقال بيمارى شود. ارزيابى دقيق ريسك انتقال ويروس، براى تعيين مناسبترين اقدام با در نظر گرفتن موارد زير ميسر مىشود: الف) ميزان انتشار

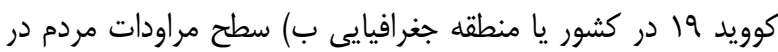
جامعه (رفت و آمدهاى محدود شده يا بدون محدوديت و آزادانه) ج) إييدميولوزى موضعى د) سنجش خطر انتقال از طريق تزريق با در مران

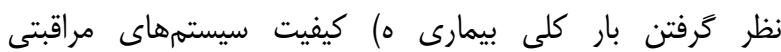

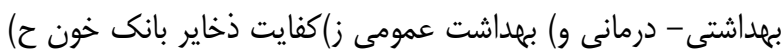
مؤثر بودن مداخلات ايمن سازى خونهاى اهدايى در كاهش ميزان ابتلا به بيمارى با توجه به وضعيت كلى كشور.

ويروس كوويد 19 در درجه اوّل توسط راههاى تنفسى منتقل

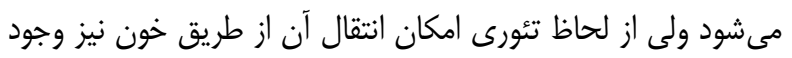

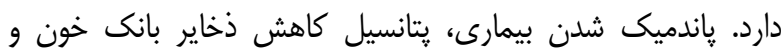

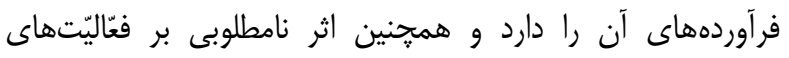
سازمانهاى انتقال خون كذاشته است. بنابراين سازمانهاى انتقال

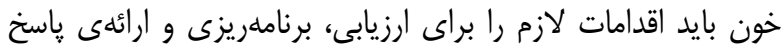

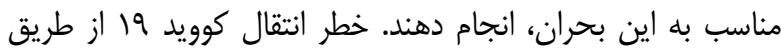

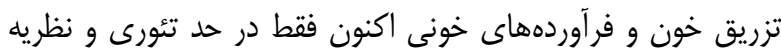

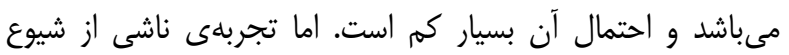

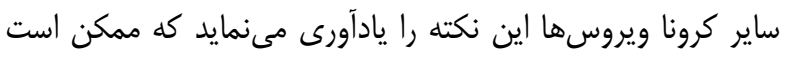

مقلهمه

علىرغم ييشرفتهاى صورت گرفته در يزشكى تاكنون هيج

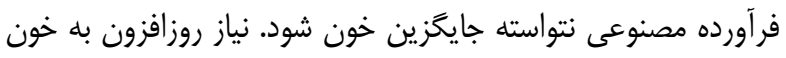

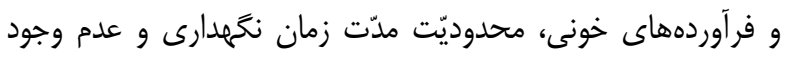

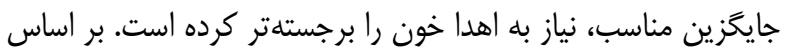

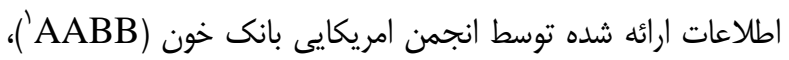
سالانه / / ميليون اهداى خون داوطلبانه انجام مى شود. با بيرتر

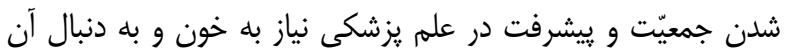

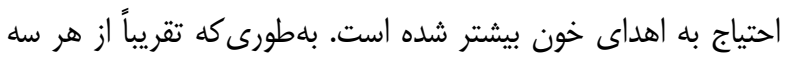

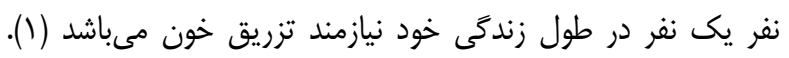

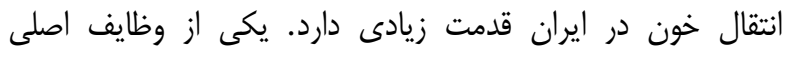

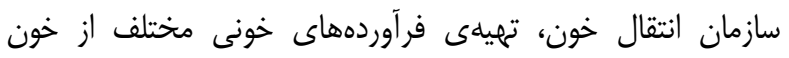

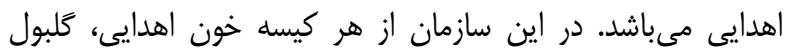

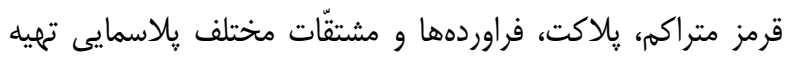

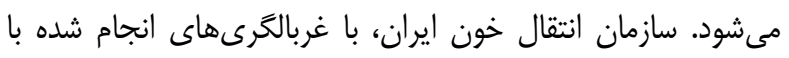

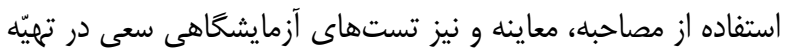

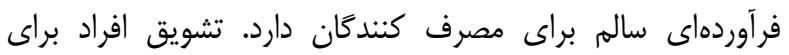
اهداى مستمر خون و استقبال مردم سبب شده شاخص اهدا در

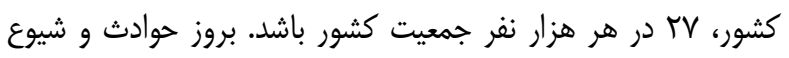
بيمارىها مىتواند بر ميزان مصرف خون و نيز تعداد موارد الهديث

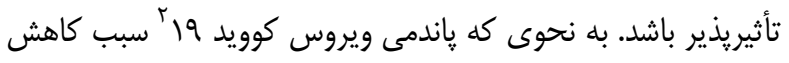

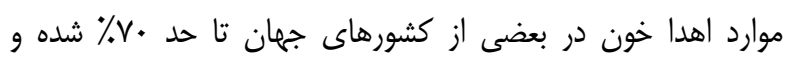
جالشهايى را ييش رو سازمانها قرار داد (ז, ب).

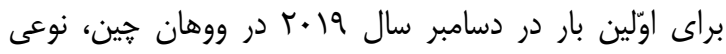

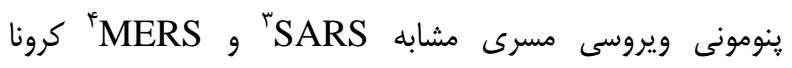

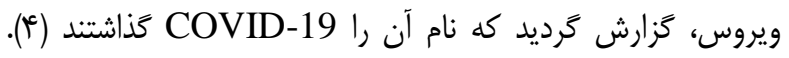
كوويد 19 يك بيمارى حاد تنفسى است كه شروع علائم بيمارى

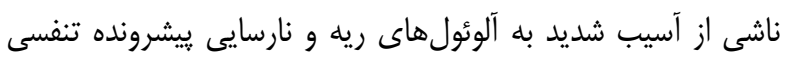
مىباشد و مىتواند در مواردى منجر به مرى و مير شود (ه).

\footnotetext{
1 American Association of Blood Banks

${ }^{2}$ Coronavirus disease 2019

${ }^{3}$ Severe Acute Respiratory Syndrome

${ }^{4}$ Middle East Respiratory Syndrome
} 


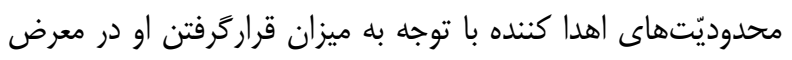

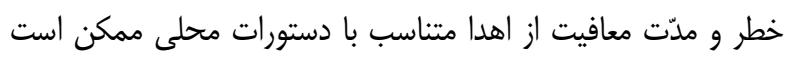

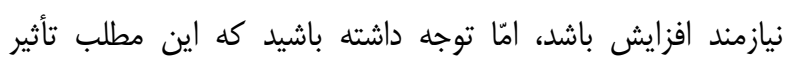

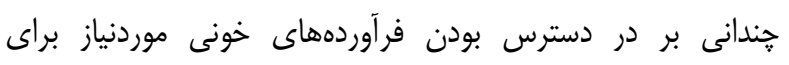

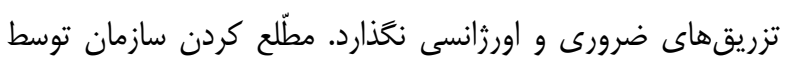

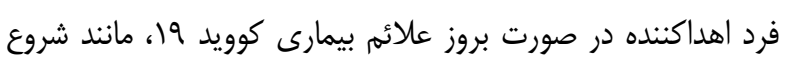

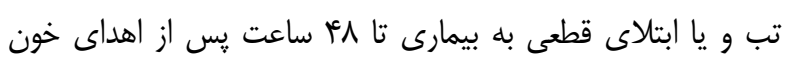

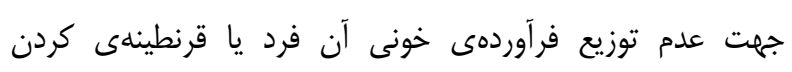

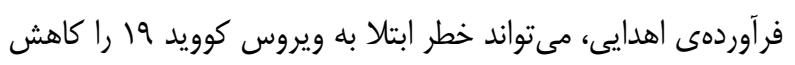
مى دهد. بايد يك سيستمى وجود داشته باشد تا اهدا كنندكان بتوانند

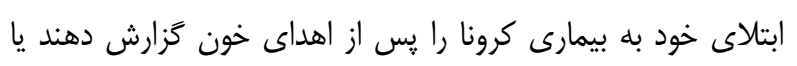

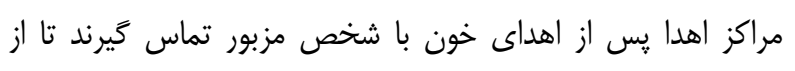

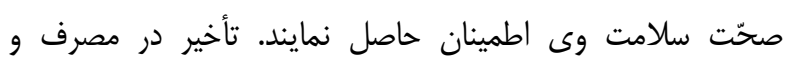

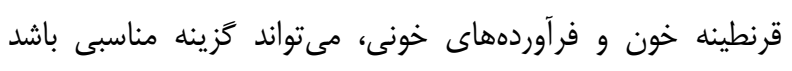

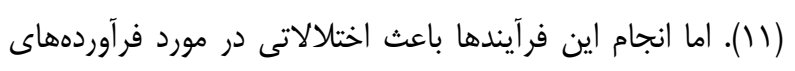

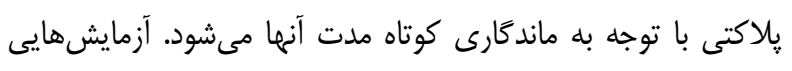
كه قبل از انتقال خون بر روى خون و فر فرآوردههاى خونى آنى انجام مىشوند، در تشخيص عفونت ويروسى در افراد مبتلا و فاقد علائم

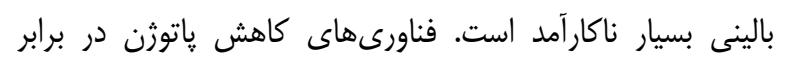
MERS-CoV و SARS-CoV و وِلاكتى مؤثر مىباشد و هزينههاى قابل توجّهى به همراه دارد.

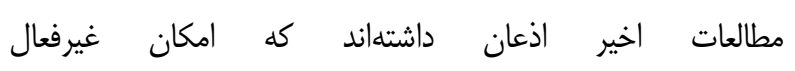
كردن Coronavirus در خون كامل وجود ندارد. استفاده از فناورىهاى كاهش ياتوزن براى ويروس كوويد 19 مقرون به صرفه نيست و توصيه نمىشود. براى كاهش هر كونه موارد احتمالى انتقال

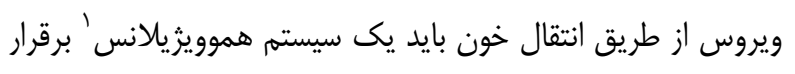
شود. اين اقدام مىتواند بسيار ارزشمند باشد.

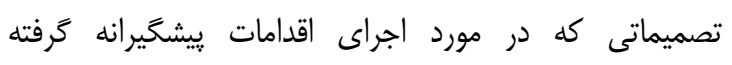
مىشود، بايد با دقّت باشد. زيرا اقدامات معرفى شده ممكن است درد

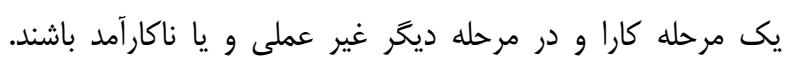

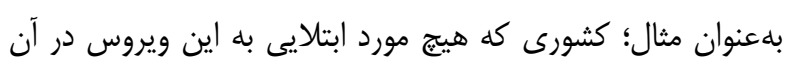

\footnotetext{
${ }^{1}$ Hemovigilance
}

با كاهش قابل توجه اهداى خون مواجه شويم (9, ^, ؟).

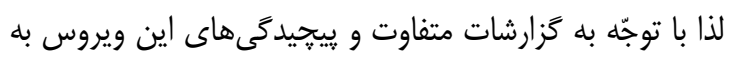

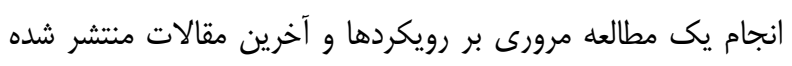

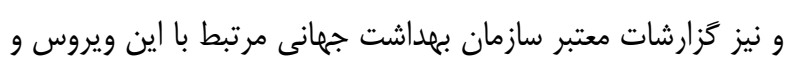

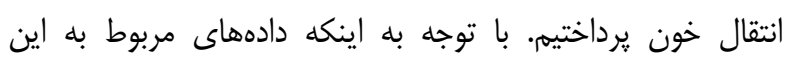

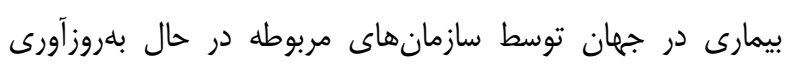

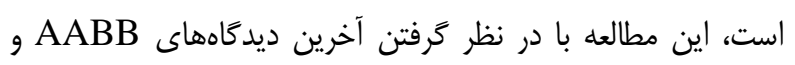
CDC

\section{يافته ها} ويروس كوويد 19 و انتقال خون

تا به حال گزارشى مبنى بر ابتلا به ويروسهاى تنفسى از از

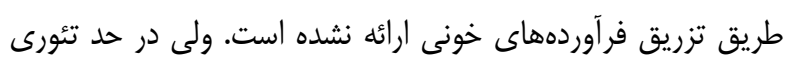
ريسك ابتلا به بيمارى از طريق فرآوردههاى خونى محتمل و مطرح

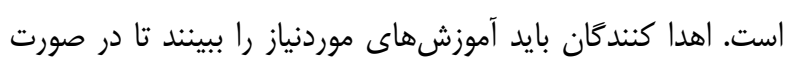

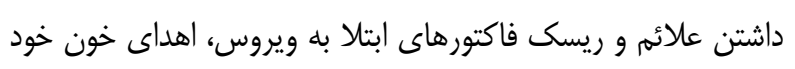

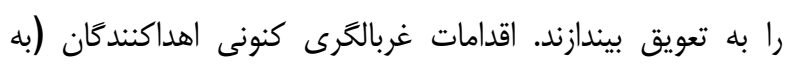

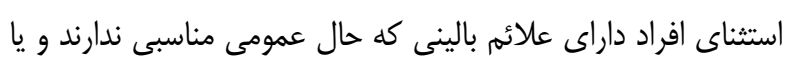

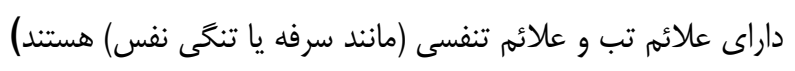

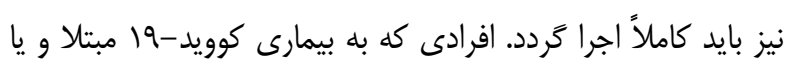

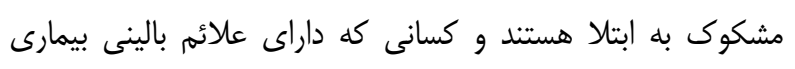

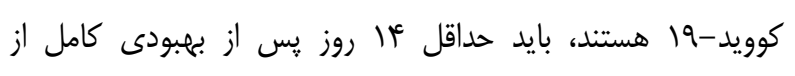
علائم از اهداى خون خوددارى كنند. همجنين كسانى كه با تأييد تستهاى آزمايشعاهى مبتلا به كوويد تشخيص داده شوند ولى هيج

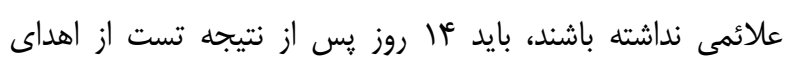

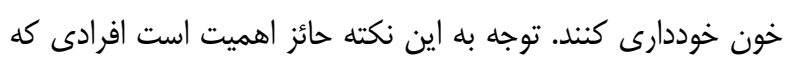

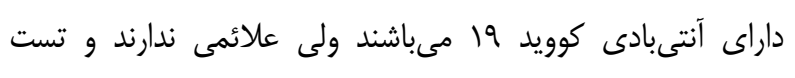
تشخيصى هم ندادهاند، بدون هيجَّونه معافيت مىتوانند به اهداى

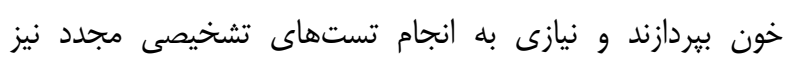

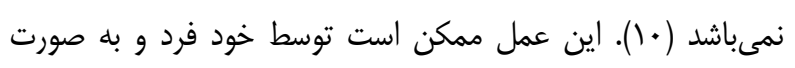

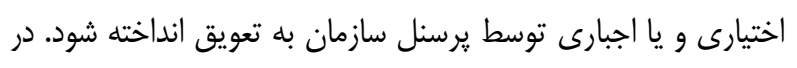

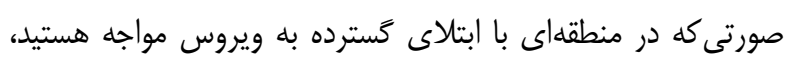


خون بايد كاملاً اهداكنندًان، كَيرندكان و مردم را به درستى آكاه كرده و اقدامات برنامهريزى شدهاى را در دستور كار خود قرار دهند. در سازمان انتقال خون، كليه كاركنان بايد تهديدهاى احتمالى عفونى و اقدامات انجام شده براى اطمينان از عرضه خون و ايمنى كارمندان و اهدا كنندگان را عملى كنند (سا, كا). تسهيل دسترسى به اهداكنندكان خون در ياندمى كوويد 19

كاهش تعداد اهداكنندكان قبل، حين و بعد از شيوع كوويد 19 يك خطر عمده براى انتقال خون محسوب مىشود. سازمان انتقال

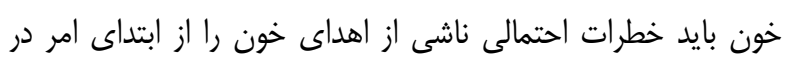

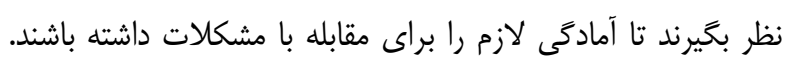

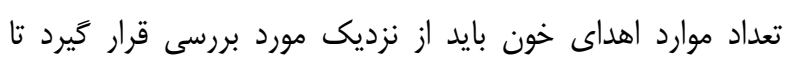

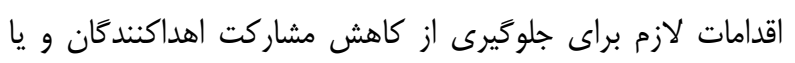

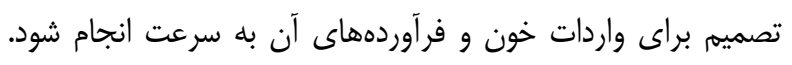

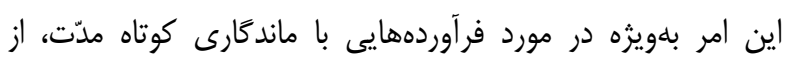

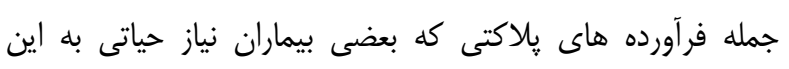

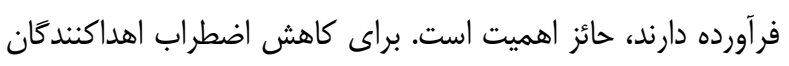

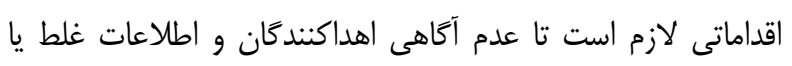
ترس از آلوده شدن در حين اهداى خون مانع كاهش موارد اهدا

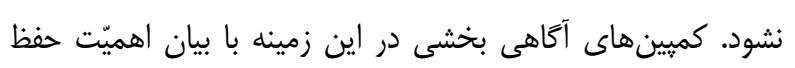

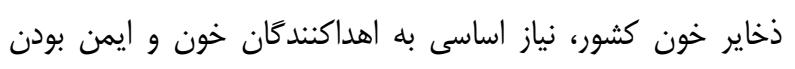
اهداى خون، مىتوانند در اين زمينه كمك شايانى نمايند. اقداماتى كه براى مهار ويروس در سطح جامعه انجام مى مشود، ممكن است ميزان حضور اهداكنندكان را در مراكز انتقال خون بران

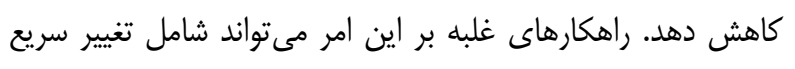

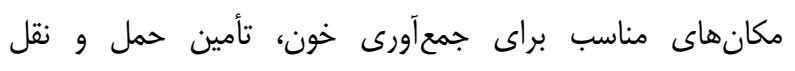

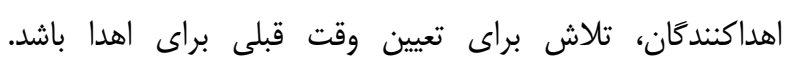

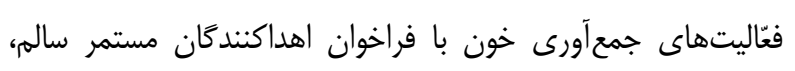

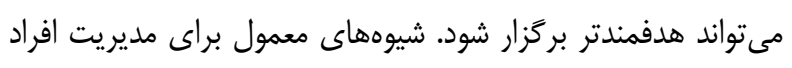

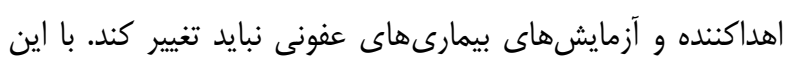
حال، در صورت كمبود شديد ذخاير خون، براى اهداكنندكان با سطح

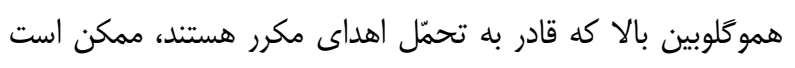

مشاهده نشده است بايد به عنوان ييشخيرى، استفاده از خون

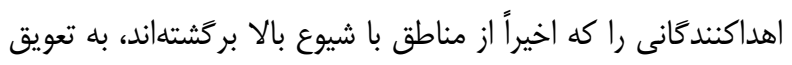

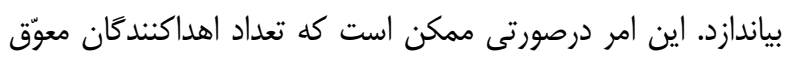

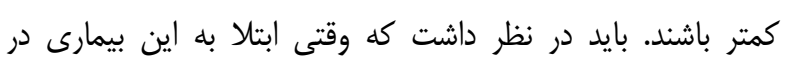
محلى شروع مىشود، خطر عمومىتر مىشود و در نتيجه شناسايى

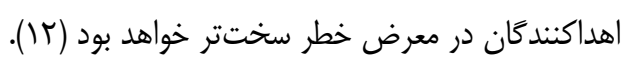

\section{حفاظت كاركنان و اهداكنندكان در برابر ويروس كوويد}

19

هر گونه انتقال ويروس از يك اهدا كننده از طريق مسيرهاى

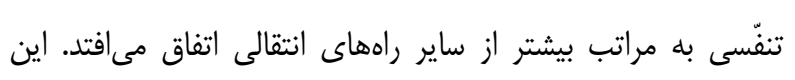

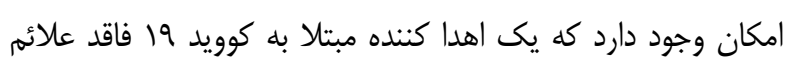

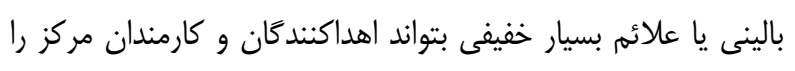

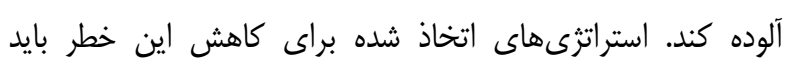

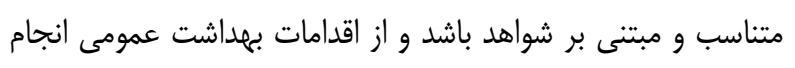

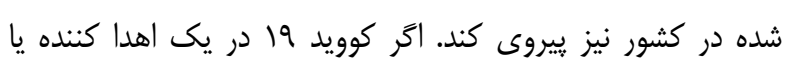

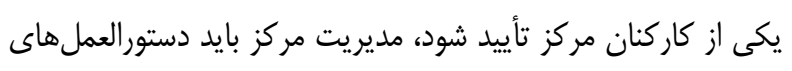

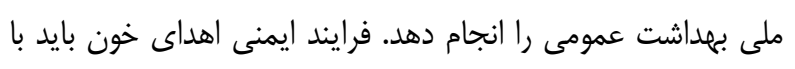
استفاده از اقدامات حفاظتى مناسب توسط كارمندان تضمين شود.

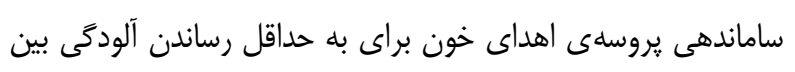

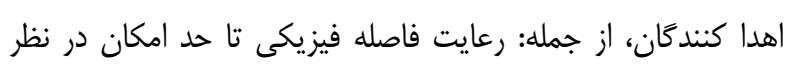

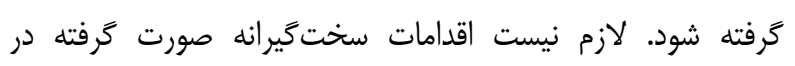
بيمارستانها در مواجهه با بيماران مبتلا به كوويد 19 در مراكز اهدات لاعدات اعمال شود، مخر اينكه مركز اهدا درون محوطه بيمارستان قرار

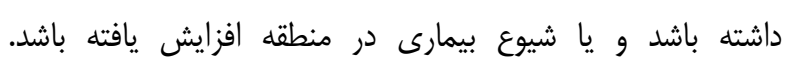

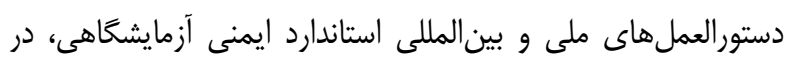

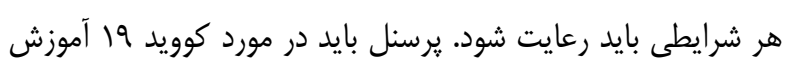

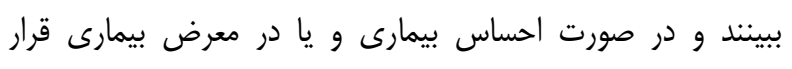

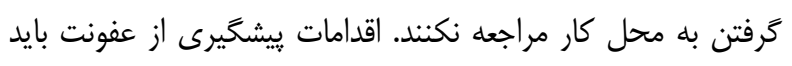
به دقت انجام شود. درصورت ابتلاى افراد زيادى در منطقه بهتر است تعديل نيرو انجام گيرد. اعتماد عمومى به سيستم اهدا و انتقال

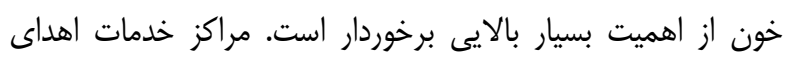


شرايط بحرانى اطمينان حاصل كنند. محدوديت تجارت و حمل و

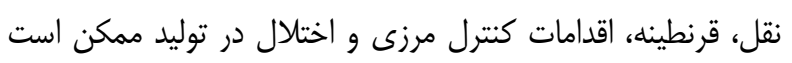

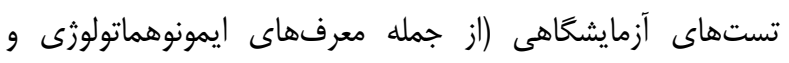

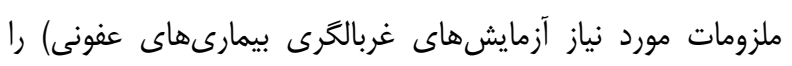
كاهش دهد. سازمانهاى انتقال خون بايد اقداماتى را براى هموار شدن عرضهى هرجه بهتر آنها انجام دهند. زنجيره تأمين جهانى تجهيزات مورد استفاده در جمعآورى خون و و

كاهش فواصل اهداى خون كامل در نظر كرفته شود. اين نكته حائر اهميت است كه اكثر افراد مبتلا به اين بيمارى ويروسى مى خوتوانند

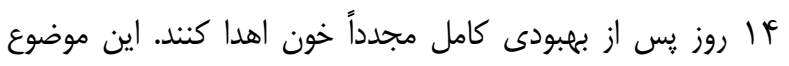

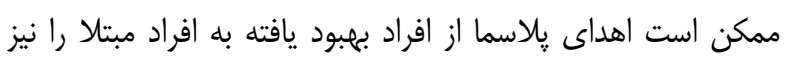

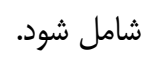
در موارد حاد، واردات خون و فرآوردههاى آن از ساير كشورها (در صورت داشتن مجوز از مراجع نظارتى)، مىتواند راه حل ديغرى

باشد.

\section{يلاسماى جمعآورى شده از بهبود يافتخان كوويد 19}

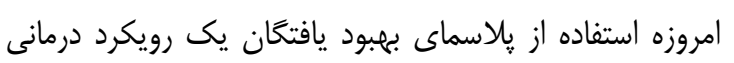

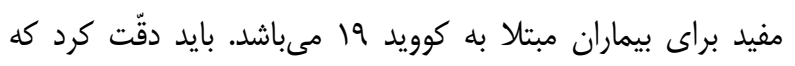

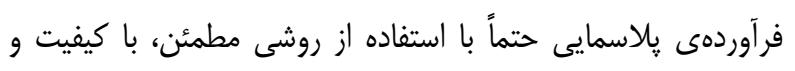

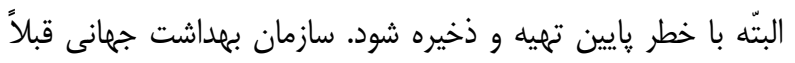

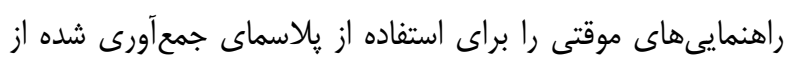

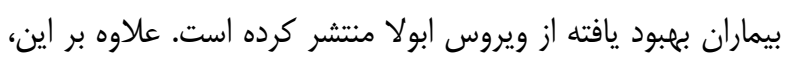
سازمان بهداشت جهانى، دستورالعملى را براى سازمانهاى انتقال

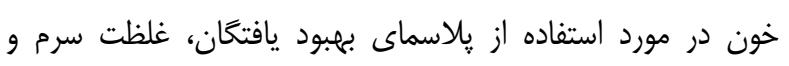
آنتىبادى در پاسخ به يك ويروس نوظهور را ارائه كرده است (r) (I).

\section{انتقال خون در إيبدمى SARS و}

در إيبدى بيمارى SARS، محقّان با بررسى خونى خون بيمارانى

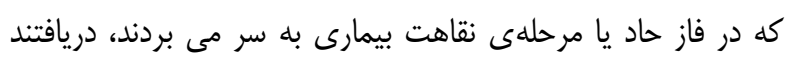
كه لنفوسيتها غلظت بسيار بالاترى از

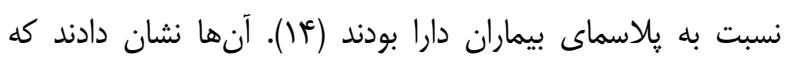
نه تنها مىتواند لنفوسيتها را آلوده كند، بلكه قادر به همانندسازى درون اين سلولها نيز مىباشد (ه) (1). يافتهها نشان

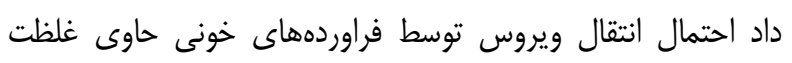

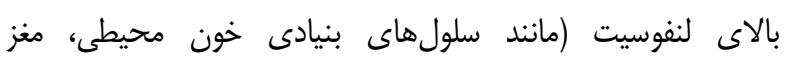
استخوان، كنسانتره گرانولوسيت و غيره) بيشتر از ساير فراوردهها

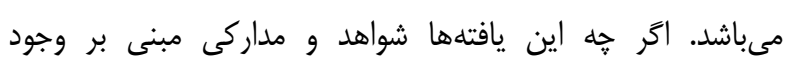
SARS-CoV

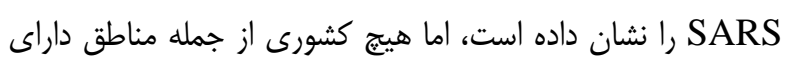

\section{مديريت درخواست خون و فرآوردههاى خونى}

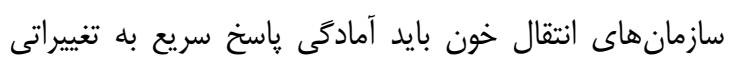
كه ممكن است منجر به كاهش ذخاير خونى شود را داشته باشند.

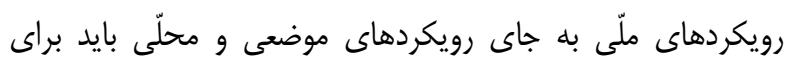

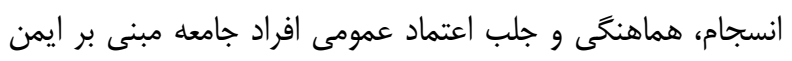

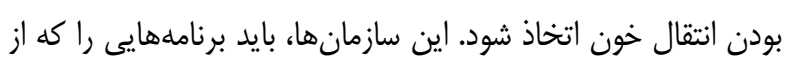

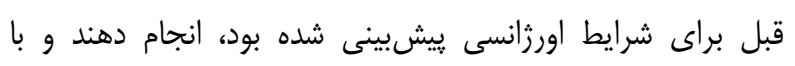

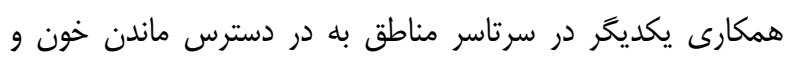
فر آوردههاى آن كمى كنند. مراكز انتقال خون بايد به طور مداوم ميزان موجودى خون خون خود را با دقّت ارزيابى كنند. در هنكام شيوع بسيار كَسترده بيمارى، تقاضا

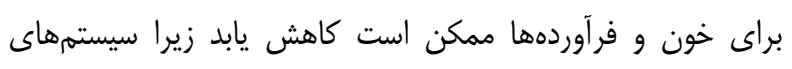
درمانى بيشتر به سمت معالجه و درمان بيماران مبتلا به كوويد 19

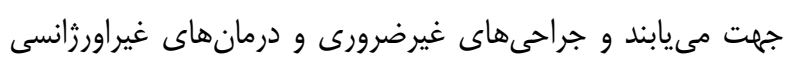

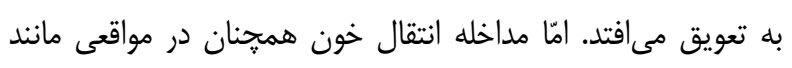

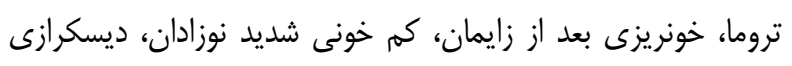
(اختلال)' خونى و جراحىهاى فورى و نيز بيماران كوويد 19 مبتلا

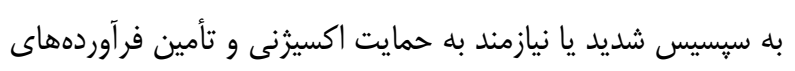
خونى بسيار حياتى است.

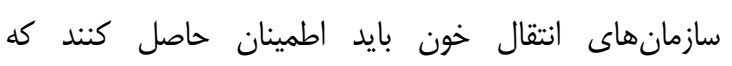
فرآوردههاى خونى تنها در موارد مناسب از نظر بالينى مورد استفاده

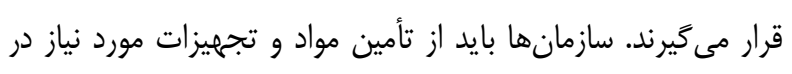

\footnotetext{
${ }^{1}$ Dyscrasia
} 


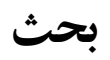

اين مطالعه، ضمن بررسى نحوهى ايمن سازى خون در زمان إيبدمى ساير كرونا ويروسهاى مشابه مانند SARS و

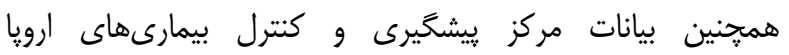
SARS- در رابطه با ميزان ريسك شيوع AABB و ('ECDC)

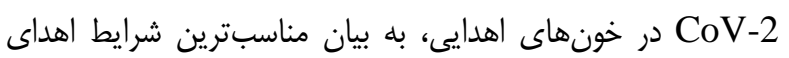

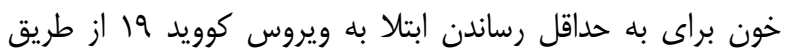

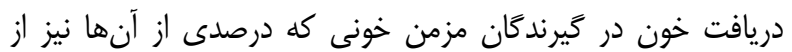
ضعف سيستم ايمنى برخوردارند، مىيردازد.

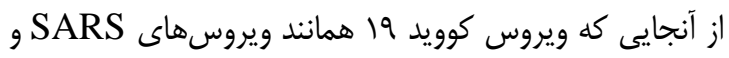

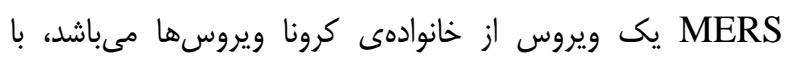

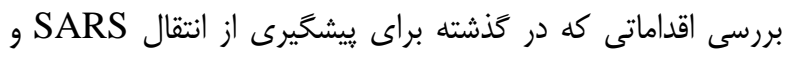
MERS مىتوان به بررسى اين نكته كه آيا اقدامات مشابه قادر به يِيشخيرى

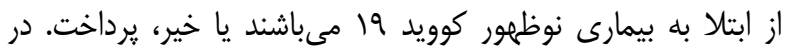

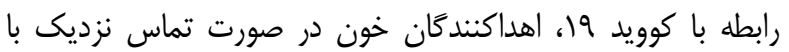
فرد مبتلا به اين بيمارى، بايد به مدت الب روز از اهداى خون معاف

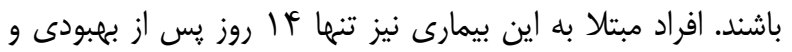
رفع كامل علائم مىتوانند براى اهداى فراوردههاى خونى به مراكز

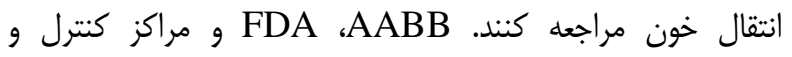
ييشگيرى از بيمارىها در حال حاضر اعلام كردند نيازى به غربالكرى فراوردههاى خونى نيست، زيرا هيج دادهاى حاكى از انتقال SARS-CoV-2

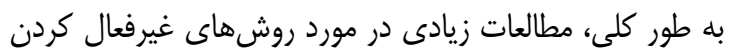

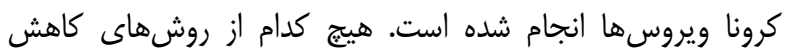

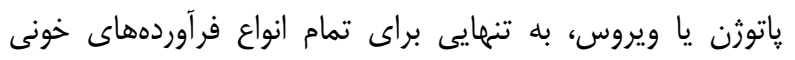

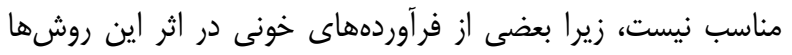

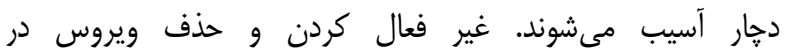

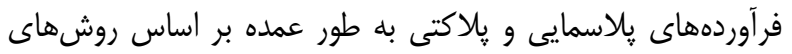

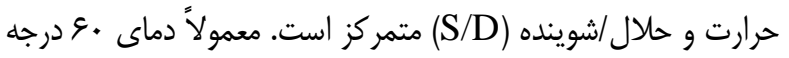

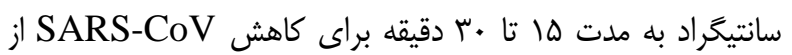

\footnotetext{
${ }^{1}$ European Centre for Disease Prevention and Control
}

شيوع بالاى SARS و هيج سازمانى از جمله WHO و AABB

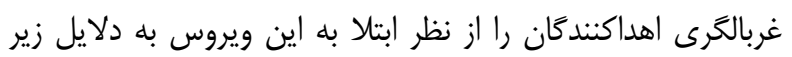
توصيه نكردند: - n

() دورهى كمون بيمارى SARS نسبتاً كوتاه است. r) تقريباً همه افراد آلوده به SARS-CoV داراى علائم شديدى و تعداد

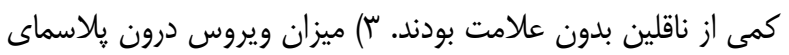
بيماران SARS كم است (ع) (1). أ) تاكنون هيج موردى از انتقال

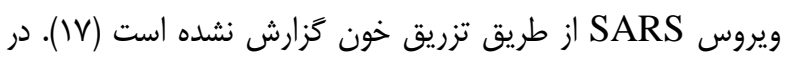

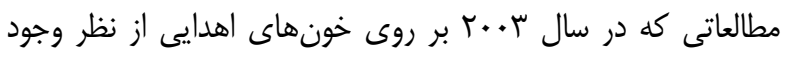
SARS-CoV RNA

در مطالعه انجام شده در خصوص بار ويروسى بر روى TV بيمار

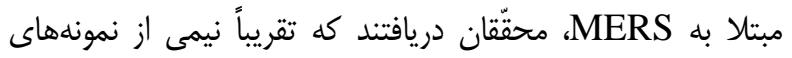

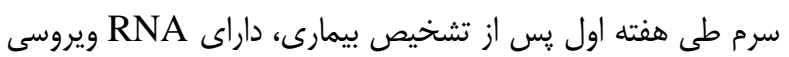

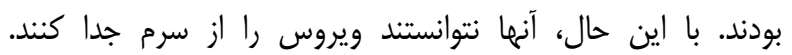

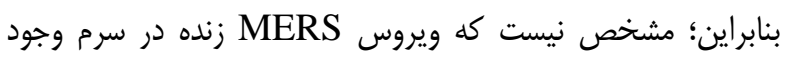

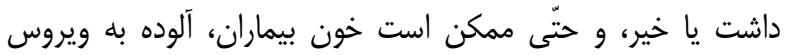

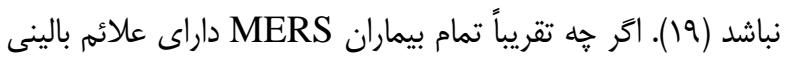
شديد هستند، ولى در عين حال در سال ها +r بيماران آتيبيكى بدون

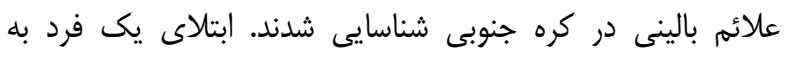
عفونت MERS-CoV با استفاده از تكنيكهاى آزمايشخاهى تأييد شد، اما در طى f روز هيج علائم بالينى مشاهده نشد. بيشتر افراد مبتلا، افراد داراى نقص در سيستم ايمنى بودند. بنابراين؛ خطر انتقال

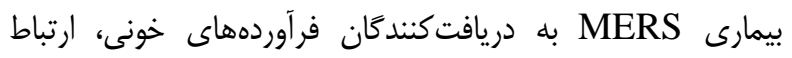
مستقيمى با ميزان ابتلاى اهداكنندًان ندارد. در نتيجه به علّت اينكه فئه تشخيص ويروس در خون نادر و ميزان بار ويروس MERS نيز درون خون كم است، FDA معيارهايى از معافيت موقّت را مانند

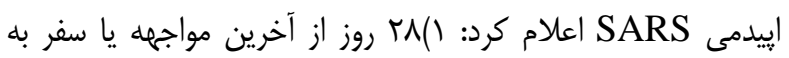

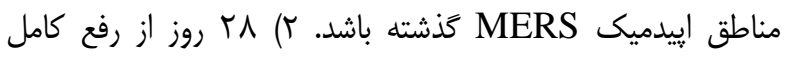
علائم و قطع درمان بيمارى MERS سيرى شده شيده باشد (•r, 19). 


\section{نتيجه كيرى}

با توجه به احتمال بروز حوادث غيرمترقبه در هر زمانى و از

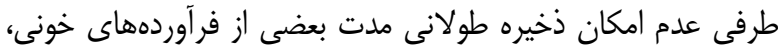

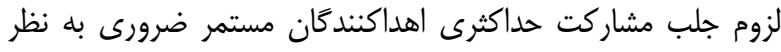
مىرسد. سازمان انتقال خون با افزايش دادن آكاهى افراد در اين خصوص از طريق رسانههاى مجازى و فراخوان آنها مىتواند نياز

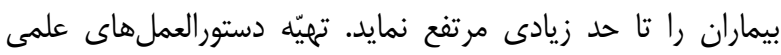
كارشناسى شده مرتبط براى بخشهاى مختلف از يذيرش تا ارسال

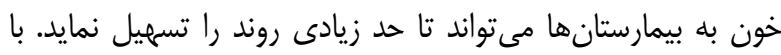

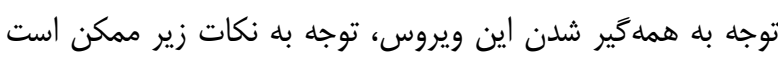

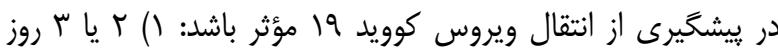
يّ از شروع علائه، RNA ويروسى در هلاسما يا سرم بيماران

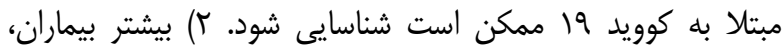
بلويزه بزرگسالان جوانى كه توانيى اهداى خون دارند، نسبت به بزر كترها علائم خفيفترى دارند. بَ) دورهى نهفتحى طولانى ويروس

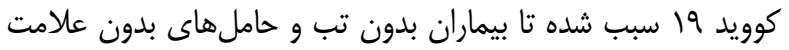

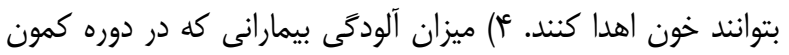
قرار دارند نامشخص است و هيج گَونه اطلاعاتى در مورد بار

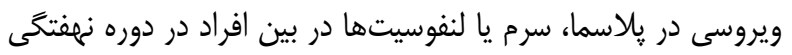

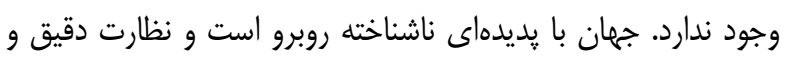

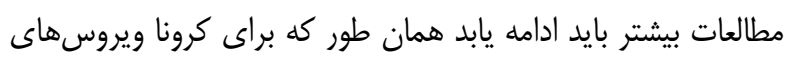
MERS و SARS غربالكرى براى شناسايى RNA ويروسى و يا آنتىبادى مربوط به

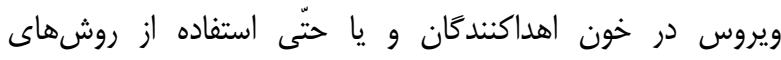

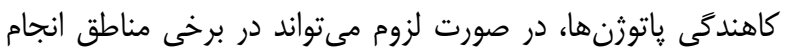

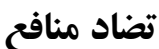

نويسندكًان مقاله اعلام مى دارند كه هيج كَنه تضاد منافعى در

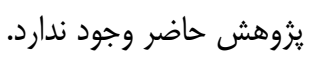

ميلاسماى بدون سلول كافى است و همين درجه حرارت به مدت .

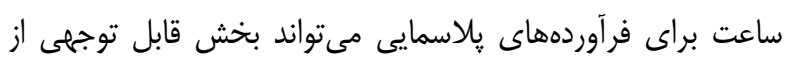

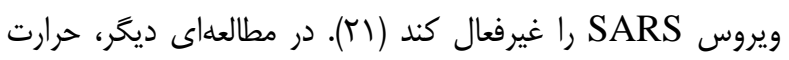

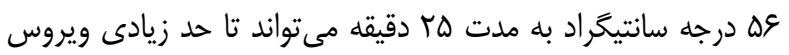

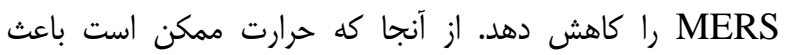
دناتوره شدن يروتئين در غشا سلولهاى خونى شود، فقط در فرآوردهاى پِاسمايى فاقد سلول، قابل استفاده است. هميحنين

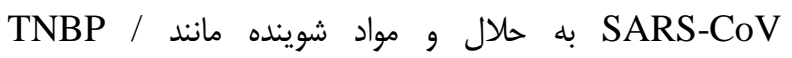
TNBP/ Tween 80 TritonX-100 روشها از جمله نور UV A, B, C با طول موجهاى مختلف و همجنين متيلن بلو فعاليت ويروس هاى SARS و و را تحت تأثير قرار مى دهند.

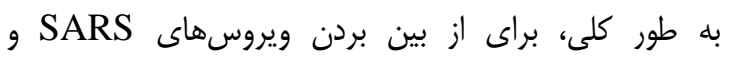

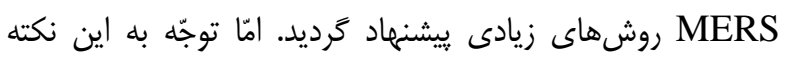
حائز اهميت است كه اين روش باعث هدر رفتن وقت شده و نيز هزينههاى كزافى را با خود به همراه دارد و همين مسئله باعث شده اهن

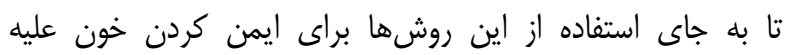
ويروس كوويد 19، بيشتر به غربالخرى و يِيشخيرى ييش از از اهدا

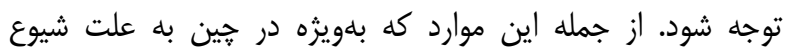
بالاى اين ويروس اجرايى شد مىتوان به موارد ذيل اشاره نمود: ( )

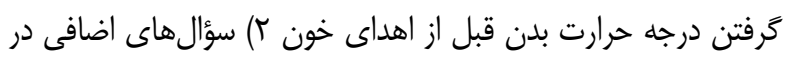

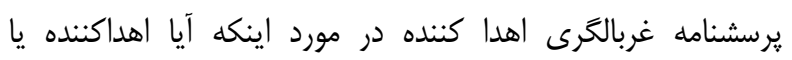

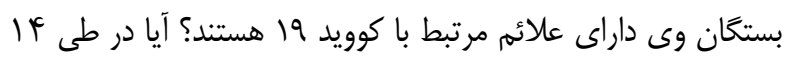

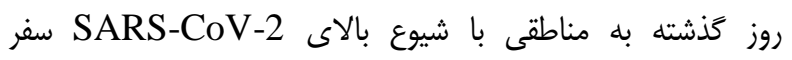

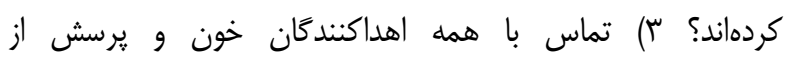
اهداكنتدكان و خانواده آنها در مورد وضعيت جسمانى كنونى آنها

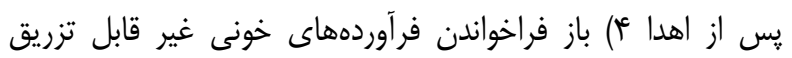

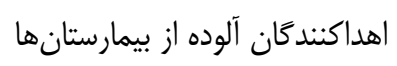
با اين حال، با توجه به تفاوتهاى بين SARS-CoV، MERS-CoV توصيههاى قبلى مورد استفاده براى SARS و MERS در مور مواجهه

$$
\text { با كوويد } 19 \text { نيز كافى هستند يا خير (بر) مودى }
$$




\section{منابع:}

1- Harmening DM. Modern blood banking \& transfusion practices. FA Davis company; $7^{\text {th }}$ edition, Philadelphia, 2018.

2- Gharehbaghian A, Abolghasemi H, Namini MT. Status of blood transfusion services in Iran. Asian J Transfus Sci. 2008; 2(1) : 13-17. DOI: 10.4103/0973-6247.39505.

3- Shan H, Zhang P. Viral attacks on the blood supply: the impact of severe acute respiratory syndrome in Beijing. Transfusion. 2004; 44(4): 467-9. DOI: 10.1111/j.0041-1132.2004.04401.X

4- Liu Y, Gayle AA, Wilder-Smith A, Rocklöv J. The reproductive number of COVID-19 is higher compared to SARS coronavirus. J Travel Med. 2020; 27(2): taaa021. DOI: 10.1093/jtm/taaa021

5- Zhou M, Zhang X, Qu J. Coronavirus disease 2019 (COVID-19): a clinical update. Front Med. 2020; 1-10. DOI: 10.1007/s11684-020-0767-8.

6- Iwen PC, Stiles KL, Pentella MA. Safety considerations in the laboratory testing of specimens suspected or known to contain the Severe Acute Respiratory Syndrome Coronavirus 2 (SARS-CoV-2). Am J Clin Pathol. 2020. DOI: 10.1093/ajcp/aqaa047.

7- Wang W, Xu Y, Gao R, Lu R, Han K, Wu G, et al. Detection of SARS-CoV-2 in different types of clinical specimens. Jama. 2020; 323(18): 1843-4. DOI: 10.1001/jama.2020.3786.

8- Kim K, Tandi T, Choi JW, Moon J, Kim M. Middle East respiratory syndrome coronavirus (MERS-CoV) outbreak in South Korea, 2015: epidemiology, characteristics and public health implications. J Hosp Infect. 2017; 95(2): 207-13. DOI: 10.1016/j.jhin.2016.10.008.

9- Teo D. Blood supply management during an influenza pandemic. ISBT Sci Ser. 2009; 4(n2): 293-8. DOI: 10.1111/j.1751-2824.2009.01283.x.

10- American Asociated of Blood Banking's resources for FDA's updated information for blood establishments regarding the COVID-19 outbreak. 2020; [cited 2020 May]. Available From: http://www.aabb.org/advocacy/regulatorygovernment/Documents/COVID-19-Toolkit.pdf. Accessed 2020 May.

11- COVID-19 and Blood Donation. 2020. Available from: https://www.nybc.org/donate-blood/covid-19-and-blooddonation-copy/\#.XoyrDddHWAI.email.

12- World Health Organization. WHO Regional Office for Europe advice on the use of experimental medicines for the treatment of COVID-19 patients, April 9 2020. World Health Organization. Regional Office for Europe; 2020. Available from: https://www.euro.who.int/en/health-topics/Health-systems/health-technologies-andmedicines/publications/2020/who-regional-office-for-europe-advice-on-the-use-of-experimental-medicines-for-thetreatment-of-covid-19-patients,-9-april-2020. Accessed 2020 May.

13- World Health Organization. Protecting the blood supply during infectious disease outbreaks: guidance for national blood services. 2019. [cited April 2019]. [Available from: https://www.who.int/bloodsafety/publications/protectingblood-supply/en/. Accessed 2020 May.

14- Wang H, Mao Y, Ju L, Zhang J, Liu Z, Zhou X,et al. Detection and monitoring of SARS coronavirus in the plasma and peripheral blood lymphocytes of patients with severe acute respiratory syndrome. Clin Chem. 2004; 50(7): 123740. DOI: 10.1373/clinchem.2004.031237.

15- Li L, Wo J, Shao J, Zhu H, Wu N, Li M,et al. SARS-coronavirus replicates in mononuclear cells of peripheral blood (PBMCs) from SARS patients. J Clin Virol. 2003; 28(3): 239-44. DOI: 10.1016/S1386-6532(03)00195-1.

16- Cheng PK, Wong DA, Tong LK, Ip SM, Lo AC, Lau CS, et al. Viral shedding patterns of coronavirus in patients with probable severe acute respiratory syndrome. Lancet. 2004; 363(9422): 1699-700. DOI: 10.1016/S0140$\underline{6736(04) 16255-7}$

17- World Health Organization. WHO recommendations on SARS and blood safety. 2003; [cited May 15, 2003]. Available from: www.who.int/csr/sars/guidelines/bloodsafety/en/; 2003 [accessed 2020-2-15]. 
18- Schmidt M, Brixner V, Ruster B, Hourfar MK, Drosten C, Preiser W, et al. NAT screening of blood donors for severe acute respiratory syndrome coronavirus can potentially prevent transfusion associated transmissions. Transfusion. 2004; 44(4): 470-5. DOI: 10.1111/j.1537-2995.2004.03269.x.

19- Corman VM, Albarrak AM, Omrani AS, Albarrak MM, Farah ME, Almasri M,et al. Viral shedding and antibody response in 37 patients with Middle East respiratory syndrome coronavirus infection. Clin Infect Dis. 2016; 62(4): 47783. DOI: 10.1093/cid/civ951.

20- Cowling BJ, Park M, Fang VJ, Wu P, Leung GM, Wu JT. Preliminary epidemiological assessment of MERS-CoV outbreak in South Korea, May to June 2015. Euro Surveill. 2015; 20(25): 7-13. DOI: 10.2807/15607917.es2015.20.25.21163.

21- Yunoki M, Urayama T, Yamamoto I, Abe S, Ikuta K. Heat sensitivity of a SARS- associated coronavirus introduced into plasma products. Vox Sang. 2004; 87(4): 302-3. DOI: $10.1111 / \mathrm{j} .1423-0410.2004 .00577 . \mathrm{x}$

22- Darnell ME, Taylor DR. Evaluation of inactivation methods for severe acute respiratory syndrome coronavirus in noncellular blood products. Transfusion. 2006; 46(10): 1770-7.

23- Chang L, Yan Y, Wang L. Coronavirus disease 2019: coronaviruses and blood safety. Transfusion medicine reviews. 2020. DOI: $10.1016 /$ j.tmrv.2020.02.003 